Doc. dr. sc. Mirjana Hladika'

Antonija Mužević, univ. spec. oec. ${ }^{2}$

\title{
IZAZOVI U IMPLEMENTACIJI I UČINCI PRIMJENE MSFI-ja 16 NAJMOVI U BANKAMA
}

\section{CHALLENGES IN IMPLEMENTATION AND EFFECTS OF THE APPLICATION OF IFRS 16 LEASES IN BANKS}

SAŽETAK: U modernom poslovnom okruženju najam predstavlja vrlo važan izvor financiranja poslovnih subjekata i glavna je alternativa bankovnom kreditu. Izvori financiranja evidentiraju se u financijskim izvještajima u skladu sa zahtjevima računovodstvenih standarda. Na snagu je 1. siječnja 2019. godine stupio MSFI 16 Najmovi kojim je promijenjen model računovodstva najmova za najmoprimce, što je posebno značajno kod najmoprimaca koji imaju sklopljene ugovore o operativnom najmu visoke vrijednosti. Ciljevi ovog rada su kroz empirijsko istraživanje identificirati i analizirati izazove u implementaciji i primjeni MSFI-ja 16 Najmovi u bankama te na temelju financijskih izvještaja banaka, kvantificirati i analizirati utjecaj primjene MSFI-ja 16 Najmovi na financijske izvještaje i financijske pokazatelje banaka u prvoj godini primjene standarda. Rezultati istraživanja pokazali su da je najveći izazov u implementaciji bila koordinacija aktivnosti između različitih odjela unutar banke, dok je najmanji izazov bio unos ugovora o operativnom najmu u sustav banke. Rezultati analize financijskih izvještaja pokazali su da je utjecaj primjene MSFI-ja 16 Najmovi na financijske izvještaje i financijske pokazatelje vidljiv kod svih banaka, ali taj utjecaj je različite značajnosti kod različitih banaka.

KLJUČNE RIJEČI: najam, MSFI 16, financijski izvještaji, financijski pokazatelji, banke

JEL: M40, M41

1 Doc. dr. sc. Mirjana Hladika, Ekonomski fakultet Sveučilišta u Zagrebu, Trg J. F. Kennedyja 6, 10000 Zagreb, e-mail: mhladika@efzg.hr

2 Antonija Mužević, univ. spec. oec., Privredna banka Zagreb d.d., Radnička cesta 50, 10000 Zagreb, e-mail: antonija.muzevic@pbz.hr

Koautorica teksta zaposlena je u Privrednoj banci Zagreb (PBZ d.d.). Navodi u tekstu isključivo su osobni stavovi i mišljenje koautorice, a ne nužno i institucije u kojoj je zaposlena.

* Ovaj rad nastao je temeljem poslijediplomskog specijalističkog rada kojeg je Antonija Mužević izradila i obranila pod mentorstvom doc. dr. sc. Mirjane Hladika. 
ABSTRACT: In a modern business environment, a lease is a very important source of financing for business entities and it is the main alternative to a bank loan. Sources of financing are recorded in financial statements in accordance with the requirements of accounting standards. IFRS 16 Leases entered into force on January 1, 2019, and it has significantly changed the accounting model for leases for the lessees. That is especially significant for lessees who have concluded operating leases agreements with high value. First objective of this paper is, through empirical research, to identify and analyze challenges in the implementation and application of IFRS 16 Leases in banks. Second goal is, based on financial statements of banks, to quantify and analyze the impact of IFRS 16 Leases on financial statements and financial indicators of banks in the first year of application of standard. The research results showed that the biggest challenge in the implementation was the coordination of activities between different departments within the bank, while the lowest challenge was the entry of operating lease agreements into the bank's system. The results of the analysis of the financial statements showed that the impact of the application of IFRS 16 Leases on the financial statements and financial indicators is visible in all banks, but this impact is of different significance in different banks.

KEY WORDS: lease, IFRS 16, financial statements, financial indicators, banks

JEL: M40, M41

\section{UVOD}

Menadžeri svakodnevno donose odluke o tome koliko je financijskih sredstava potrebno poslovnom subjektu, u kojem roku su sredstva potrebna, u kojem roku se sredstva trebaju vratiti te načinu pribavljanja potrebnih sredstava. Sredstva se mogu pribaviti iz vlastitih ili tuđih izvora financiranja, a s ciljem da se zadovolje financijske potrebe poslovnog subjekta vrlo često se kombiniraju vlastiti i tuđi izvori financiranja. U dijelu tuđih izvora financiranja, najam predstavlja vrlo značajan izvor financiranja poslovnih subjekata te se smatra glavnom alternativom bankovnom kreditu. U modernom poslovnom okruženju, najam je vrlo važan izvor financiranja poslovnih subjekata u svim sektorima te se njime financiraju različite vrste imovine (postrojenja i strojevi, zrakoplovi, osobna i gospodarska vozila i druga prijevozna sredstva, nekretnine, računala i drugo). Najam omogućava poslovnim subjektima dostupnost i korištenje imovine bez značajnih odljeva financijskih sredstava na početku (PWC, 2016). Statistički podaci potvrđuju koliki je značaj najma kao izvora financiranja poslovnih subjekata. Tako je ukupna aktiva leasing društava u Republici Hrvatskoj na kraju 2019. godine iznosila 21.321 milijuna kuna, najviše je bilo aktivnih ugovora o najmu osobnih i gospodarskih vozila, a najmoprimci su najvećim dijelom bili poslovni subjekti iz nefinancijskog sektora, zatim financijske institucije, stanovništvo (domaćinstva) i državne jedinice (HANFA, 2020). Prema izvješću ERA-e (eng. European Rental Association), u poslovnim subjektima koji se bave iznajmljivanjem opreme ukupan prihod od najma opreme u 2018. godini iznosio je više od 26 bilijuna EUR-a, što predstavlja povećanje od 4,4\% u odnosu na prethodnu godinu (ERA, 2019). Prema izvješću Leaseeurope-a, ukupna vrijednost aktivnih ugovora o najmu automobila u 2018. godini iznosila je 832,6 bilijuna EUR-a (Leaseeurope, 2019). 
Odbor za Međunarodne računovodstvene standarde (IASB) objavio je u siječnju 2016. godine novi standard za računovodstvo najmova - Međunarodni standard financijskog izvještavanja (MSFI) 16 Najmovi (dalje u tekstu: MSFI 16). MSFI 16 stupio je na snagu 1. siječnja 2019. godine te je zamijenio dotadašnji standard za računovodstvo najmova - Međunarodni računovodstveni standard (MRS) 17 Najmovi (dalje u tekstu: MRS 17). Stupanjem na snagu MSFI-ja 16 značajno je promijenjen računovodstveni tretman najma kod najmoprimca (kod najmodavca nema promjene) te je uveden jedinstveni model računovodstva najmova za najmoprimce, što znači da kod najmoprimca nestaje podjela najmova na financijski i operativni najam. MRS 17 bio je fokusiran na identifikaciju i podjelu najmova na financijski i operativni najam pri čemu se u financijskim izvještajima najmoprimca prikazivao samo financijski najam. Operativni najam bio je predmet izvanbilančne evidencije i kao takav nije bio prezentiran u financijskim izvještajima najmoprimca. Upravo netransparentnost informacija o imovini i obvezama po osnovi operativnog najma u financijskim izvještajima najmoprimca bila je osnovni razlog i pokretač promjene modela računovodstva najmova. Najznačajnija promjena koja je uvedena MSFI-jem 16 odnosi se na kapitalizaciju operativnog najma u financijskim izvještajima najmoprimca odnosno priznavanje imovine s pravom uporabe za svaki najam te istovremeno priznavanje $\mathrm{i}$ iskazivanje obveze po osnovi najma. Time operativni najam na velika vrata ulazi i postaje vidljiv u poslovnim knjigama i financijskim izvještajima najmoprimca (Hladika, 2018). Promjena računovodstvenog tretmana najma kod najmoprimca u skladu je sa zahtjevom da se svi izvori financiranja poslovnog subjekta prezentiraju u njegovim financijskim izvještajima. U kontekstu obveznika primjene MSFI-ja 16, važno je istaknuti da u Republici Hrvatskoj tek oko 360 (0,3 \%) poduzetnika jesu veliki poduzetnici i subjekti od javnog interesa koji su obveznici primjene MSFI-jeva.

Primjena MSFI-ja 16 i kapitalizacija operativnih najmova dovodi do promjena u financijskim izvještajima najmoprimca budući da se u bilanci obvezno iskazuju imovina s pravom uporabe i obveze po osnovi najma, a to posljedično utječe i na financijske pokazatelje najmoprimca. Koliki će biti utjecaj na financijske izvještaje i financijske pokazatelje najmoprimca ovisi o tome kolika je ukupna vrijednost ugovora o operativnom najmu, koliki je iznos ukupne aktive najmoprimca, ali i o djelatnosti kojom se najmoprimac bavi. Također, važno je istaknuti da implementacija svakog novog standarda, pa tako i MSFI-ja 16, zahtijeva organizirani i sveobuhvatni pristup implementaciji i prilagodbu poslovnih procesa u poslovnom subjektu, te angažman ljudskih i materijalnih resursa. U skladu s navedenim, prvi je cilj ovog rada kroz empirijsko istraživanje identificirati i analizirati izazove u implementaciji i primjeni MSFI-ja 16 u bankama. Drugi cilj ovog rada je, na temelju financijskih izvještaja banaka, kvantificirati i analizirati utjecaj primjene MSFI-ja 16 na financijske izvještaje i financijske pokazatelje banaka u prvoj godini primjene standarda.

Ostatak rada organiziran je kako slijedi: najprije je dan pregled prethodnih istraživanja vezano uz područje ovog rada, zatim je prikazano empirijsko istraživanje o implementaciji i primjeni MSFI-ja 16 u bankama koje uključuje metodologiju istraživanja i analizu rezultata istraživanja, potom su prikazani rezultati istraživanja utjecaja primjene MSFI-ja 16 na financijske izvještaje i financijske pokazatelje u bankama te zaključak. Od znanstvenih metoda, u radu su korištene metoda analize, sinteze, deskripcije, klasifikacije, komparacije te odabrane metode deskriptivne i inferencijalne statistike. 


\section{PREGLED LITERATURE}

\subsection{Promjena modela računovodstva najmova}

Model računovodstva najmova kako je bio definiran u posljednjoj verziji MRS-a 17 primjenjivao se od 1997. godine. MRS 17 zahtijevao je priznavanje i iskazivanje financijskog najma u bilanci najmoprimca, dok se operativni najam iskazivao izvanbilančno. Prema tom modelu računovodstva najmova, najmoprimci u svojoj bilanci nisu iskazivali imovinu i obveze po osnovi operativnog najma (tzv. izvanbilančni najmovi) uslijed čega korisnici financijskih izvještaja (financijski analitičari, investitori, kreditori i drugi) nisu bili u mogućnosti objektivno ocijeniti financijski položaj najmoprimca te ocijeniti njegovu stvarnu zaduženost. Zbog toga je takav model računovodstva najmova bio višestruko kritiziran od strane korisnika (Beattie, Goodacre i Thomson, 2006), praktičara i znanstvenika (Reither, 1998).

Brojni poslovni subjekti imali su veliki broj i značajnu vrijednost ugovora o operativnom najmu za različite vrste imovine (vozila, nekretnine, postrojenja, računala i drugo), ali obveze po toj osnovi ostale su prikrivene budući da su ti poslovni subjekti u svojim financijskim izvještajima iskazivali samo trošak mjesečne najamnine za operativni najam, ali nisu prikazivali buduće obveze do kraja ugovora o operativnom najmu. Tipični primjeri poslovnih subjekata i sektora sa značajnim iznosima ugovora o operativnom najmu jesu maloprodaja, aviokompanije, hoteli i telekomunikacije (Morales-Díaz i Zamora-Ramírez, 2018). Duke, Hsieh i Su (2009) u svom su istraživanju ukazali na činjenicu da brojni poslovni subjekti koriste prednosti što ih donosi operativni najam u smislu izbjegavanja bilančnog iskazivanja stvarnih obveza po osnovi operativnog najma te koriste operativni najam kao vrlo važan izvor financiranja svog poslovanja. Stoga je IASB nastojao MSFI-jem 16 stati na kraj skrivanju budućih obveza u financijskim izvještajima najmoprimca koje proizlaze iz sklopljenih ugovora o operativnom najmu te na taj način osigurati svim zainteresiranim korisnicima financijskih izvještaja transparentno prikazivanje svih relevantnih informacija vezanih uz najmove. Također, IASB očekuje da će primjena MSFI-ja 16 dovesti do značajnog poboljšanja kvalitete financijskih izvještaja i to prvenstveno za one najmoprimce koji imaju sklopljene ugovore o operativnom najmu značajne vrijednosti.

MSFI-jem 16 uveden je jedinstveni model računovodstva najmova za najmoprimce prema kojem je najmoprimac na datum početka najma dužan priznati imovinu s pravom uporabe i obveze po osnovi najma (MSFI 16, točka 22.). Imovina s pravom uporabe i obveze po osnovi najma prestat će se priznavati u računovodstvenoj evidenciji i u bilanci najmoprimca prilikom isteka ili prekida ugovora o najmu. Najmoprimac ima mogućnost koristiti izuzeća od primjene ovog zahtjeva samo za kratkoročne najmove (najmove do 12 mjeseci) i najmove imovine male vrijednosti (do 5.000 USD).

\subsection{Ključni izazovi u implementaciji i primjeni MSFI-ja 16 Najmovi}

Utjecaj promjene računovodstvene regulative u području najmova na najmoprimce ovisi o zastupljenosti najmova u njihovom redovnom poslovanju. Prije stupanja na snagu MSFI-ja 16 ugovori o operativnom najmu evidentirali su se u izvanbilančnoj evidenciji, te im najmoprimci nisu pridavali veliku pozornost. Međutim, stupanjem na snagu MSFI-ja 16 , najmoprimci su morali konvertirati sve ugovore o operativnom najmu iz izvanbilančne evidencije u bilančnu evidenciju, a uz to su bili primorani napraviti prilagodbu poslovnih 
procesa. Na slici 1. prikazano je kako su najmoprimci, uslijed implementacije MSFI-ja 16, trebali napraviti prilagodbu politika, procedura, kontrola, administracije, poreznih pitanja, te IT sustava i procesa.

Slika 1. Utjecaj MSFI-ja 16 Najmovi na poslovne procese najmoprimca

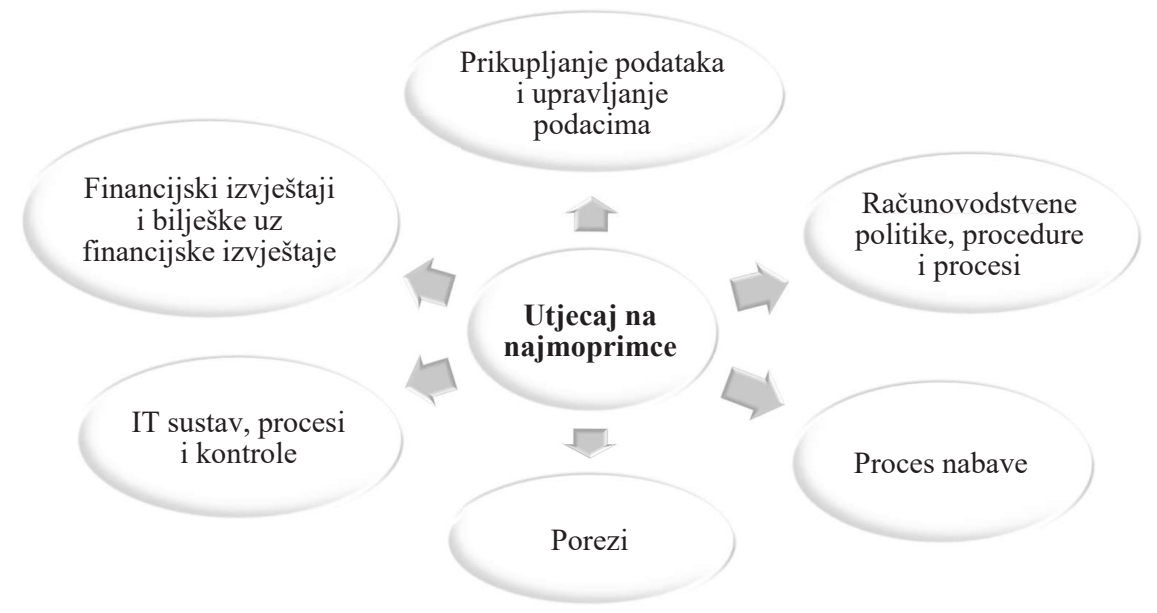

Izvor: obrada autora prema IFRS Foundation (2016). Leases: A summary of IFRS 16 and its effects.

Na temelju slike 1. može se zaključiti da je prilagodba poslovnih procesa kod najmoprimca zahtijevala suradnju različitih organizacijskih dijelova te da se ne radi samo o aktivnosti odjela financija i računovodstva. Potrebne prilagodbe u procesu prikupljanja podataka o najmovima ovise o tome kako su najmoprimci imali organizirane podatke, sustave, procese i kontrole za vrijeme primjene MRS-a 17. Na datum stupanja na snagu MSFI-ja 16 bilo je potrebno prikupiti financijske i nefinancijske podatke o ugovorima o najmu kako bi se osigurala dostatna razina analitičkih podataka. Stoga je razumljivo da su najmoprimci koji su imali dobro organiziranu podršku upravljanja ugovorima u najmu, kao i kvalitetnu računovodstvenu podršku trebali napraviti manje prilagodbe procesa u odnosu na one koji to nisu imali. Važno pitanje odnosilo se i na IT rješenje koje će omogućiti potrebnu evidenciju ugovora o najmovima u skladu sa zahtjevima MSFI-ja 16. U tom dijelu, najmoprimci su trebali donijeti odluku hoće li nadograđivati postojeće IT sustave ili će investirati u nove. Pri tome je bilo potrebno uvažiti dva ključna ograničenja, a to su vrijeme i financijska sredstva koja su im bila na raspolaganju.

U cilju što bolje pripreme za implementaciju MSFI-ja 16, najmoprimci su se koristili različitim metodama i načinima, kao na primjer edukacijom organizacijskih dijelova koji su vezani uz proces ugovaranja, evidencijom i prezentiranjem podataka iz ugovora o najmu, formiranjem projekta i planiranjem detaljnih projektnih aktivnosti te utvrđivanjem postojeće situacije s ciljem dijagnosticiranja potrebnih promjena.

Koliko je sama implementacija MSFI-ja 16 zahtjevna i kompleksna ovisi o broju i vrsti sklopljenih ugovora o najmu, roku na koji su sklopljeni ugovori o najmu, predmetu najma, komponentama ugovora o najmu te dostupnosti podataka o sklopljenim ugovorima o najmu. Kompleksnost implementacije utječe na troškove implementacije MSFI-ja 16. U tablici 1. sistematizirani su faktori koji utječu na kompleksnost implementacije MSFI-ja 16. 
Tablica 1. Faktori koji utječu na kompleksnost implementacije MSFI-ja 16 Najmovi

\begin{tabular}{|l|l|}
\hline Kompleksna implementacija & Manje kompleksna implementacija \\
\hline $\begin{array}{l}\text { Većina ugovora o najmu su ugovori o } \\
\text { operativnom najmu }\end{array}$ & $\begin{array}{l}\text { Većina ugovora o najmu su ugovori o } \\
\text { financijskom najmu }\end{array}$ \\
\hline $\begin{array}{l}\text { Većina ugovora o najmu je na dugi rok } \\
\text { (npr. ugovor o najmu poslovne zgrade) }\end{array}$ & $\begin{array}{l}\text { Većina ugovora o najmu je na kratki rok } \\
\text { do } 12 \text { mjeseci i male su vrijednosti }\end{array}$ \\
\hline $\begin{array}{l}\text { Podaci o ugovorima o najmu nalaze se u } \\
\text { priručnim evidencijama }\end{array}$ & Podaci o ugovorima o najmu su dostupni \\
\hline $\begin{array}{l}\text { Ugovori o najmu sadrže komponentu naj- } \\
\text { ma i usluge }\end{array}$ & $\begin{array}{l}\text { Ugovori o najmu ne sadrže komponentu } \\
\text { najma i usluge }\end{array}$ \\
\hline $\begin{array}{l}\text { Ugovori o najmu se odnose na različite } \\
\text { predmete najma s različitim uvjetima } \\
\text { najma }\end{array}$ & $\begin{array}{l}\text { Ugovori o najmu odnose se na sličnu } \\
\text { imovinu sa sličnim uvjetima najma }\end{array}$ \\
\hline
\end{tabular}

Izvor: obrada autora prema IFRS Foundation (2016). Leases - A summary of IFRS 16 and its effects.

U kontekstu implementacije i primjene MSFI-ja 16, Murphy (2016) i Deloitte (2016) su istaknuli i ključne izazove. Najmoprimci trebaju sagledati kako se najmovi koriste u postojećem poslovanju s ciljem da se utvrdi utjecaj na postojeći poslovni model, strateške planove najmoprimca, kao i na odluku o tome da li imovinu kupiti ili unajmiti. Najmoprimci trebaju napraviti pregled (reviziju) postojećih ugovora o najmu i to posebno odredbi koje se odnose na varijabilne iznose renti, odredbi koje sadrže komponente ugovora te odredbi koje sadrže opciju kupnje i povećanja rente. Najmoprimci trebaju procijeniti da li promjene u bilanci (zbog priznavanja najma) utječu na financijske pokazatelje, a posljedično i na uvjete za odobravanje kredita. U tom dijelu, važno je procijeniti i porezni tretman najmova. Izazov predstavlja i tehničko rješenje koje će najmoprimci primijeniti za potrebe računovodstvene evidencije najmova te u tom smislu trebaju odlučiti hoće li kupiti novi softver ili će nadograditi postojeći. Za očekivati je da će ugovori o najmu biti u pojačanom fokusu interne i eksterne revizije te se zahtijeva sveobuhvatna evidencija ugovora o najmovima. Potrebna je i revizija politike o klasifikaciji najmova na operativne i financijske. Izazov predstavlja i utvrđivanje inkrementalne kamatne stope u slučajevima kada ju najmodavac nije iskazao u ugovoru o najmu. Najmoprimac treba utvrditi postupke za razumnu, dosljednu i dokumentiranu procjenu komponenti ugovora o najmu, što je relevantno kad ugovor o najmu sadrži najam i dio koji se ne odnosi na najam. Najmoprimci trebaju donijeti odluku o načinu inicijalne primjene MSFI-ja 16 u skladu sa standardom odnosno hoće li primijeniti puni retroaktivni ili modificirani retroaktivni pristup. Izazovi su prisutni i kod priznavanja te naknadnog mjerenja imovine s pravom uporabe i obveza po osnovi najma.

\subsection{Pregled prethodnih istraživanja}

Primjena MSFI-ja 16 uzrokovala je određene promjene u financijskim izvještajima najmoprimca pri čemu su najznačajnije promjene vidljive u bilanci zbog priznavanja i iskazivanja imovine s pravom uporabe i obveze po osnovi najma. Posljedično, MSFI 16 može utjecati i na financijske pokazatelje koji se računaju na temelju podataka iz bilance (likvid- 
nost i zaduženost). U računu dobiti i gubitka i u izvještaju o novčanim tokovima dolazi do promjene pozicija na kojima se iskazuju učinci ugovora o operativnom najmu. U računu dobiti i gubitka promjene nastaju na razini pojedinačnog izvještajnog razdoblja, ali na razini ukupnog trajanja ugovora o najmu nema promjene iz razloga što su troškovi vezani uz ugovor o operativnom najmu kroz cijeli period trajanja najma jednaki prema MRS-u 17 i prema MSFI-ju 16. Razlika je u tome što se prema MRS-u 17 trošak najamnine iskazivao kao operativni trošak i time je utjecao na operativnu dobit, a prema MSFI-ju 16 evidentiraju se troškovi amortizacije koji se iskazuju kao operativni troškovi, dok troškovi kamata predstavljaju financijske rashode. Posljedično, utjecaj je vidljiv u povećanju EBITDA-e budući da se prema MSFI-ju 16 pri izračunu u obzir uzimaju troškovi kamata i troškovi amortizacije, a prema MRS-u 17 u izračun su se u obzir uzimali samo troškovi najamnine. IASB smatra da će odvojeno prikazivanje troškova kamata i troškova amortizacije vezanih uz ugovor o operativnom najmu investitorima i financijskim analitičarima pružiti važne informacije za donošenje odluka (IFRS Foundation, 2016). MSFI 16 ne utječe na iznos novčanog toka koji je iskazan u izvještaju o novčanim tokovima, već su promjene vidljive u načinu prezentiranja stavki vezanih uz ugovor o operativnom najmu u samom izvještaju. Novčani izdaci za kamate iskazuju se kao novčani izdaci od poslovnih aktivnosti (odnosno, u skladu sa zahtjevima MRS-a 7 Izvještaj o novčanim tokovima), a novčani izdaci za otplatu glavnice iskazuju se kao novčani izdaci od financijskih aktivnosti. Prema MRS-u 17, plaćanja s osnove operativnog najma iskazivala su se kao novčani izdaci od poslovnih aktivnosti.

Brojna su istraživanja provedena s ciljem utvrđivanja utjecaja promjene modela računovodstva najmova i kapitalizacije operativnih najmova u financijskim izvještajima najmoprimca na financijski položaj, uspješnost poslovanja te na financijske pokazatelje najmoprimca. Važno je istaknuti da su sva istraživanja provedena prije primjene MSFI-ja 16. Beattie, Edwards i Goodacre (1998) analizirali su utjecaj kapitalizacije operativnog najma na ključne financijske pokazatelje na slučajnom uzorku od 300 kotiranih kompanija u Velikoj Britaniji. Istraživanje uključuje razdoblje od 1990. do 1994. godine. Rezultati su pokazali da će kapitalizacija najma imati značajan utjecaj na financijske izvještaje (,u prosjeku neprijavljena dugoročna obveza predstavljala je $39 \%$ prijavljenog dugoročnog duga, dok je neprijavljena imovina predstavljala $6 \%$ ukupne imovine"). Rezultati su pokazali da će kapitalizacija operativnog najma imati značajan utjecaj na odabrane financijske pokazatelje - maržu profita, ROA i pokazatelje zaduženosti. Bennett i Bradbury (2003) analizirali su očekivani utjecaj kapitalizacije operativnog najma na financijske izvještaje i ključne financijske pokazatelje na uzorku od 38 kompanija koje kotiraju na Novozelandskoj burzi u 1995. godini. Rezultati istraživanja pokazali su da kapitalizacija operativnog najma ima značajan utjecaj na financijski položaj poslovnog subjekta. U svojoj studiji utvrdili su prosječno povećanje ukupne imovine za $8,8 \%$ i ukupnih obveza za $22,9 \%$ te smanjenje kapitala za $3 \%$. Rezultati su pokazali da će zaduženost značajno porasti, dok se očekuje da će se profitabilnost i likvidnost smanjiti. Durocher (2008) je istraživao utjecaj kapitalizacije operativnog najma na bilancu i ključne financijske pokazatelje na uzorku 100 najvećih kanadskih kotirajućih kompanija (iz svih sektora) za 2002. i 2003. godinu. Rezultati su pokazali da kapitalizacija operativnog najma dovodi do značajnog povećanja ukupne imovine i ukupnih obveza najmoprimca. Kao posljedica toga, utvrđeno je značajno smanjenje koeficijenta tekuće likvidnosti i značajno povećanje pokazatelja zaduženosti. Također, u ovom istraživanju je navedeno da bi kapitalizacija operativnog najma trebala imati značajne učinke na profitabilnost samo u određenim segmentima industrije poput trgovine i smještaja, nafte, 
plina i financijskih usluga. Morales-Díaz i Zamora-Ramírez (2018) istraživali su utjecaj kapitalizacije operativnog najma na financijske izvještaje i financijske pokazatelje najmoprimaca na uzorku od 646 kotiranih europskih kompanija (iz svih sektora) te su dokazali da kapitalizacija operativnog najma ima značajan utjecaj na bilancu i pokazatelje zaduženosti. U svom su istraživanju dokazali da utjecaj na financijske izvještaje i financijske pokazatelje ovisi o djelatnosti (sektoru) kojom se pojedini poslovni subjekt bavi. Na temelju rezultata dobivenih istraživanjem, oni su utvrdili da je najznačajniji utjecaj vidljiv kod poslovnih subjekta koji posluju u maloprodaji, hotelima i prijevozu. Veverková (2019) je utvrdila na uzorku od 15 europskih zrakoplovnih kompanija kojima je operativni najam glavni izvor financiranja da će kapitalizacija operativnih najmova dovesti do povećanja ukupne imovine i dugoročnih obveza te smanjenja kapitala. Također, u svom je istraživanju istaknula da će primjena MSFI-ja 16 i kapitalizacija operativnih najmova dovesti do pogoršanja pokazatelja zaduženosti, ali i do promjene pokazatelja profitabilnosti najmoprimaca. Pored navedenih, istraživanja o utjecaju promjene modela računovodstva najma i kapitalizacije operativnog najma u bilanci najmoprimca proveli su i do sličnih rezultata došli i sljedeći autori: Fülbier, Silva i Pferdehirt (2008), Singh (2012), Fitó, Moya i Orgaz (2013), Wong i Joshi (2015), Bohušová (2015), Hladika i Valenta (2018).

Slična su očekivanja vezano uz utjecaj primjene MSFI-ja 16 na financijske izvještaje i financijske pokazatelje banke kao najmoprimca. MSFI 16 će imati značajan utjecaj na banke i druge subjekte koji pružaju financijske usluge koji imaju razgranatu mrežu podružnica, velike administrativne i call centre, razgranatu mrežu bankomata i pripadajućeg prostora koji zauzimaju takvi uređaji, uređaje za pohranu podataka, eksternalizirane usluge i aranžmane s pružateljima takvih usluga (Deloitte, 2019). Kapitalizacija ugovora o operativnom najmu utjecat će na kapitalne zahtjeve banke (Deloitte, 2019; Hassan, 2018). MSFI 16 će utjecati i na poslovanje banaka kroz pružanje temeljnih bankovnih usluga. Utjecaj će biti vidljiv primarno kroz proces odobravanja kredita budući da klijenti banke koji traže kredit, a istodobno imaju značajnu vrijednost ugovora o operativnom najmu, uslijed primjene MSFI-ja 16 imaju pogoršane pokazatelje zaduženosti. Klijenti s lošijim pokazateljima zaduženosti ocjenjuju se rizičnijim klijentima što utječe na izračun očekivanih kreditnih gubitaka i posljedično uzrokuje dodatan pritisak na kapital banke.

\section{EMPIRIJSKO ISTRAŽIVANJE O IMPLEMENTACIJI I PRIMJENI MSFI-ja 16 NAJMOVI U BANKAMA}

\subsection{Metodologija istraživanja}

Prvi cilj ovog rada je identificirati i analizirati izazove u implementaciji i primjeni MSFI-ja 16 u bankama. U svrhu ostvarenja ovog cilja, tijekom studenoga 2019. godine provedeno je empirijsko istraživanje putem anketnog upitnika na uzorku banaka sa sjedištem u Republici Hrvatskoj. Anketni upitnik dostavljen je putem e-maila na adrese 20 banaka koje su imale odobrenje za rad prema popisu Hrvatske narodne banke od 8. 11. 2019. godine. ${ }^{3}$ Anketnim upitnikom nije se zahtijevala identifikacija ispitanika (banaka), nego se je tražio

Podaci o kreditnim institucijama koje imaju odobrenje za rad nalaze se na sljedećoj poveznici: https:// www.hnb.hr/temeljne-funkcije/supervizija/popis-kreditnih-institucija. 
podatak o iznosu aktive banke na dan 30. 06. 2019. godine kako bi se odredila reprezentativnost uzorka. U istraživanju je sudjelovalo 10 banaka, a njihova aktiva iznosila je $84 \%$ ukupne aktive svih banaka koja je na dan 30. 06. 2019. godine iznosila 412 milijardi kuna. ${ }^{4}$ Podaci prikupljeni istraživanjem sistematizirani su u Excel dokumentu koji je korišten kao input za obradu podataka. Podaci prikupljeni istraživanjem obrađeni su odabranim metodama deskriptivne i inferencijalne statistike (Pearsonov koeficijent korelacije).

U nastavku se analiziraju i objašnjavaju rezultati istraživanja relevantni za ostvarenje ciljeva ovog rada.

\subsection{Analiza rezultata istraživanja}

Razumijevanje i primjena MSFI-ja 16 Najmovi. Pitanjima u prvom dijelu anketnog upitnika ispitivalo se dijele li ispitanici mišljenje Odbora za međunarodne računovodstvene standarde o ključnim pitanjima (prednostima) vezanim uz primjenu MSFI-ja 16 (tablica 2.).

Tablica 2. Stavovi ispitanika o tvrdnjama vezanim uz primjenu MSFI-ja 16 Najmovi

\begin{tabular}{|l|c|c|c|c|c|}
\hline Tvrdnja & $\begin{array}{c}\text { U pot- } \\
\text { puno- } \\
\text { sti se } \\
\text { slažem }\end{array}$ & $\begin{array}{c}\text { Slažem } \\
\text { se }\end{array}$ & $\begin{array}{c}\text { Niti se } \\
\text { slažem } \\
\text { niti se ne } \\
\text { slažem }\end{array}$ & $\begin{array}{c}\text { Ne } \\
\text { slažem } \\
\text { se }\end{array}$ & $\begin{array}{c}\text { U pot- } \\
\text { punosti } \\
\text { se ne } \\
\text { slažem }\end{array}$ \\
\hline $\begin{array}{l}\text { 1. Primjenom MSFI-ja 16 Najmovi } \\
\text { ugovori o najmu prikazivat će se } \\
\text { transparentnije u financijskim izv- } \\
\text { ještajima }\end{array}$ & 2 & 6 & 0 & 2 & 0 \\
\hline $\begin{array}{l}\text { 2. Primjenom MSFI-ja 16 Najmovi } \\
\text { korisnici financijskih izvještaja imat } \\
\text { ce točniji/realniji uvid u financijski } \\
\text { položaj kreditne institucije }\end{array}$ & 2 & 7 & 0 & 1 & 0 \\
\hline $\begin{array}{l}\text { 3. Kreditna institucija će se zaduži- } \\
\text { vati po višim kamatnim stopama } \\
\text { budući da je stupanj zaduženosti } \\
\text { primjenom MSFI-ja 16 Najmovi } \\
\text { veći }\end{array}$ & 0 & 1 & 4 & 4 & 1 \\
\hline $\begin{array}{l}\text { 4. Promatrajući globalno, na razini } \\
\text { tržišta kao cjeline, koristi od prim- } \\
\text { jene MSFI-ja 16 Najmovi veće su } \\
\text { od troškova }\end{array}$ & 0 & 3 & 3 & 3 & 1 \\
\hline
\end{tabular}

Izvor: vlastito istraživanje.

Zanimljivo je istaknuti da se većina ispitanika (60 \%) slaže s tvrdnjom da cee se primjenom MSFI-ja 16 ugovori o najmu transparentnije prikazivati u financijskim izvještajima, dok $70 \%$ ispitanika ističe da će korisnici financijskih izvještaja imati realniji uvid u

Podaci dostupni na internetskoj stranici Hrvatske narodne banke, Privremeni nerevidirani podaci za kreditne institucije, na dan 30. 06. 2019. godine. 
financijski položaj kreditne institucije. Nadalje, 40 \% ispitanika se ne slaže, a $40 \%$ njih je indiferentno prema tvrdnji da će se nakon implementacije MSFI-ja 16 kreditne institucije zaduživati po višim kamatnim stopama zbog povećanja stupnja zaduženosti kreditne institucije kao najmoprimca. Finalno, 60 \% ispitanika se ne slaže ili je indiferentno prema tvrdnji da su koristi od primjene MSFI-ja 16 veće od troškova.

Ugovori o najmu. U drugom dijelu anketnog upitnika cilj je bio ispitati koliki je broj sklopljenih ugovora o najmu u pojedinoj banci, koja je najčešća vrsta imovine koja je predmet ugovora o najmu te kolika je vrijednost sklopljenih ugovora o najmu. Rezultati istraživanja su pokazali da $50 \%$ banaka ima sklopljenih do 100 ugovora o najmu, $10 \%$ banaka ima sklopljeno između 101 i 300 ugovora o najmu, dok ostalih $40 \%$ banaka ima sklopljeno između 301 i 500 ugovora o najmu. Broj sklopljenih ugovora o najmu korelira s veličinom banke odnosno veći broj sklopljenih ugovora o najmu imaju veće banke (prema kriteriju iznosa aktive).

Kao predmet ugovora o najmu u bankama najčešće se javlja sljedeća imovina: poslovne nekretnine, stanovi, namještaj, motorna vozila, IT oprema i IT sustavi, bankomati i ostalo. Ovdje je zanimljivo istaknuti da sve banke (100\%) imaju sklopljene ugovore o najmu poslovne nekretnine, $80 \%$ banaka koristi motorna vozila koja su u najmu, a $50 \%$ banaka ima sklopljene ugovore o najmu bankomata, IT opreme i IT sustava (grafikon 1.).

Grafikon 1. Vrsta imovine koja je predmet ugovora o najmu

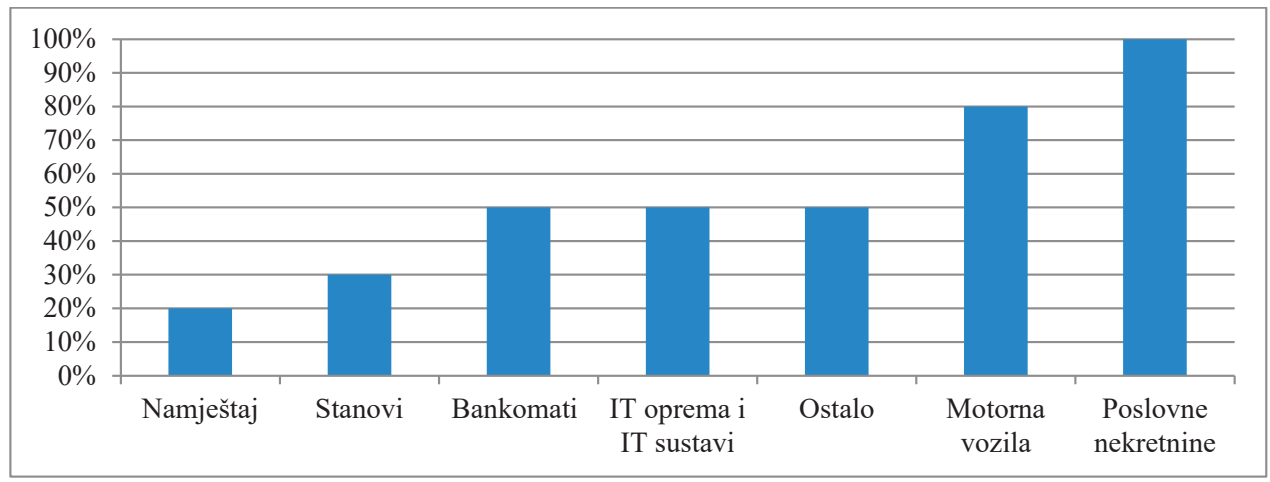

Izvor: vlastito istraživanje.

Što se tiče vrijednosti sklopljenih ugovora o najmu, najveći je udio banaka (70 \%) u kojima vrijednost sklopljenih ugovora o najmu iznosi do 100 milijuna kuna, kod $20 \%$ banaka vrijednost sklopljenih ugovora o najmu iznosi između 100 i 200 milijuna kuna, dok kod $10 \%$ banaka vrijednost sklopljenih ugovora o najmu iznosi između 300 i 600 milijuna kuna.

Implementacija MSFI-ja 16 Najmovi. Pitanja vezana uz implementaciju i sam tijek implementacije MSFI-ja 16 bila su sadržana u trećem i petom dijelu anketnog upitnika. Rezultati istraživanja pokazali su da je kod 70 \% banaka implementacija MSFI-ja 16 bila realizirana kroz poseban projekt, kod $20 \%$ banaka nije bilo posebnog projekta za implementaciju ovog standarda, a $10 \%$ banaka je u vrijeme provedbe ovog istraživanja još uvijek bilo u procesu implementacije MSFI-ja 16. Ovdje je važno istaknuti da otvaranje posebnog projekta za implementaciju MSFI-ja 16 nije u korelaciji s veličinom banke (prema kriteriju 
iznosa aktive). Sam proces implementacije trajao je od 1 do 3 mjeseca kod $30 \%$ banaka, $40 \%$ banaka završilo je proces implementacije u razdoblju od 3 do 6 mjeseci, dok je $20 \%$ banaka proces implementacije MSFI-ja 16 provodilo u razdoblju od 6 do 9 mjeseci.

Kroz istraživanje se ispitalo koji su odjeli unutar banke sudjelovali u procesu implementacije MSFI-ja 16. Utvrđeno je da je odjel financija i računovodstva sudjelovao u implementaciji ovog standarda u svim bankama, a kod $40 \%$ banaka ovaj je odjel ujedno bio i jedini odjel koji je provodio implementaciju. Uz odjel financija i računovodstva, u implementaciji MSFI-ja 16 najčešće su još sudjelovali odjel informatike i odjel za nabavu, dok odjel za upravljanje rizicima u nijednoj banci nije sudjelovao u implementaciji.

Interni i eksterni troškovi implementacije MSFI-ja 16 za $50 \%$ banaka iznosili su do 100.000 kuna, kod $20 \%$ banaka troškovi su iznosili između 100.001 i 200.000 kuna, kod $10 \%$ banaka troškovi su iznosili između 200.001 i 400.000 kuna, dok su kod samo jedne banke troškovi iznosili više od 800.001 kuna. Važno je istaknuti da troškovi implementacije MSFI-ja 16 pozitivno koreliraju s veličinom banke odnosno da su manje banke iskazale niže troškove implementacije (do 100.000 kuna), a kod velikih banaka troškovi implementacije značajno variraju nakon što premaše iznos od 100.000 kuna.

Na temelju rezultata istraživanja u okviru ovog dijela anketnog upitnika može se zaključiti da su „male“ banke implementaciju MSFI-ja 16 realizirale kroz poseban projekt u roku od 6 mjeseci, da su troškovi implementacije iznosili do 100.000 kuna te da je u implementaciju bio uključen samo odjel financija i računovodstva. S druge strane, kod „velikih“ banaka nije moguće utvrditi povezanost između troškova implementacije, vremena koje je bilo potrebno za implementaciju i činjenice je li implementacija realizirana kroz poseban projekt. $^{5}$

Primjena svakog novog standarda pa tako i MSFI-ja 16, pred banke i ostale poslovne subjekte stavlja brojne i različite izazove u procesu implementacije, a kasnije i same primjene. U tom smislu, jedan dio anketnog upitnika bio je usmjeren na ključne izazove banaka u procesu implementacije MSFI-ja 16 (grafikon 2.). Najveći izazov pri implementaciji MSFI-ja 16 u bankama bila je koordinacija aktivnosti između različitih odjela unutar banke (kod $90 \%$ ispitanika). Utvrđivanje inkrementalne kamatne stope, priprema podataka za izvještajne potrebe (interne i eksterne) te definiranje računovodstvenog tretmana najmova predstavljaju izazove od iste važnosti za $80 \%$ ispitanika i zauzimaju drugo mjesto po značajnosti. Kao najmanji izazov pri implementaciji navode se definiranje ugovora o najmu i unos ugovora o najmu u sustav banke.

Pristupi rješavanju ovih izazova bili su različiti u pojedinim bankama. Tako je najveći udio banaka (60 \%) rješavanju izazova pristupio dodatnim angažmanom internih resursa (IT, poslovni sektori). Dio ispitanika (40 \%) koristio je i usluge vanjskih konzultanata, podršku matičnog društva te su sudjelovali na edukacijama i treninzima kako bi otklonili nedoumice i dvojbe vezane uz primjenu MSFI-ja 16. Kupovinu novog IT rješenja za evidenciju i vođenje ugovora o najmu primijenilo je $40 \%$ ispitanika.

Za potrebe analize podataka prikupljenih anketnim upitnikom, „,malim“ bankama nazvane su one banke čija aktiva je iznosila do $2 \%$ ukupne aktive svih banaka, a „velikim“ bankama nazvane su one banke čija aktiva je iznosila više od $2 \%$ ukupne aktive svih banaka u Republici Hrvatskoj, promatrano na dan 30. 06. 2019. godine. 
Grafikon 2. Izazovi pri implementaciji MSFI-ja 16 Najmovi u bankama

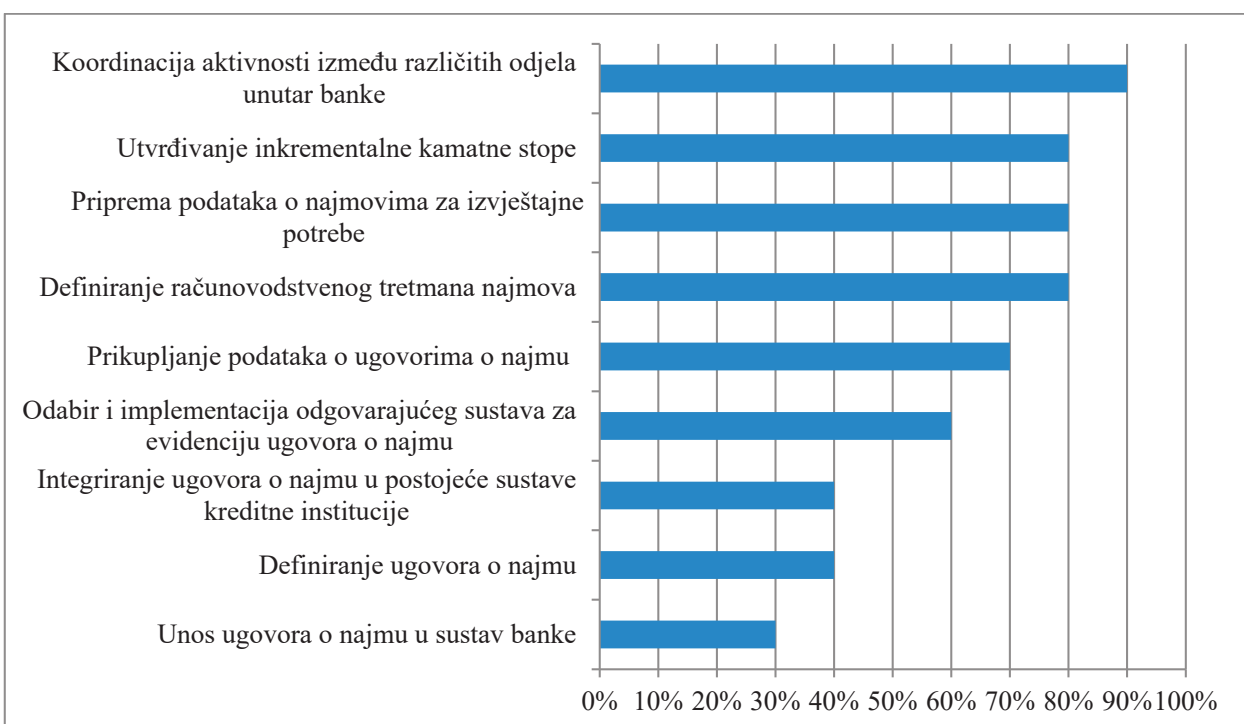

Izvor: vlastito istraživanje.

Pearsonov koeficijent korelacije primijenjen je u cilju utvrđivanja linearne povezanosti između promjene računovodstvenog tretmana najmova koji je definiran u MSFI-ju 16 i odabranih područja koja koriste ili procesuiraju računovodstvene informacije o najmovima. Povezanost između računovodstvenog tretmana najmova i odabranih varijabli prikazana je u tablici 3.

Tablica 3. Statistička povezanost između računovodstvenog tretmana najmova i odabranih varijabli

\begin{tabular}{|l|c|}
\hline \multicolumn{1}{|c|}{ Varijable } & $\begin{array}{c}\text { Pearsonov koefici- } \\
\text { jent korelacije }\end{array}$ \\
\hline Računovodstveni tretman najma i izvještaj o financijskom položaju & 0,4826 \\
\hline $\begin{array}{l}\text { Računovodstveni tretman najma i eksterno izvještavanje (prema } \\
\text { HNB-u, ECB-u) }\end{array}$ & 0,4521 \\
\hline $\begin{array}{l}\text { Računovodstveni tretman najma i interno izvještavanje (prema me- } \\
\text { nadžmentu, za potrebe vlasnika) }\end{array}$ & 0,4138 \\
\hline Računovodstveni tretman najma i interni procesi & 0,3924 \\
\hline Računovodstveni tretman najma i IT sustav & 0,3657 \\
\hline Računovodstveni tretman najma i financijski pokazatelji & 0,3211 \\
\hline Računovodstveni tretman najma i prihodi i rashodi & 0,2139 \\
\hline
\end{tabular}

Izvor: izračun autora.

Na temelju dobivenih rezultata može se zaključiti da, prema Dumičić i sur. (2011) između promatranih varijabli postoji slaba pozitivna veza. 


\section{ISTRAŽIVANJE UTJECAJA PRIMJENE MSFI-ja 16 NAJMOVI, NA FINANCIJSKE IZVJEŠTAJE I FINANCIJSKE POKAZATELJE U BANKAMA}

Računovodstvene informacije objavljuju se u financijskim izvještajima te predstavljaju jedan od najvažnijih inputa za donošenje kratkoročnih i dugoročnih poslovnih odluka internih i eksternih korisnika. U modernom poslovnom okruženju, od temeljne važnosti za financijsko izvještavanje jesu pitanja o tome koje se informacije objavljuju u financijskim izvještajima, kada se informacije objavljuju te koja su to kvalitativna obilježja informacija koja ih čine korisnima (Gulin i sur., 2018). Financijski izvještaji pružaju informacije o financijskom položaju, uspješnosti poslovanja, novčanim tokovima te informacije o promjenama kapitala poslovnog subjekta. Promjena iznosa iskazanih u financijskim izvještajima utječe na financijske pokazatelje. Analiza financijskih izvještaja provodi se s ciljem obrade podataka prezentiranih u financijskim izvještajima kako bi se poboljšala informacijska podloga za potrebe upravljanja i odlučivanja. Proces analize financijskih izvještaja uključuje korištenje čitavog niza različitih postupaka, među kojima su horizontalna i vertikalna analiza, te financijski pokazatelji koji su ujedno i najznačajniji dio analize financijskih izvještaja (Žager i sur., 2020). Iz navedenog proizlazi drugi cilj rada: na temelju financijskih izvještaja banaka, kvantificirati i analizirati utjecaj primjene MSFI-ja 16 na financijske izvještaje i financijske pokazatelje banaka u prvoj godini primjene standarda.

U svrhu ostvarenja ovog cilja korišteni su financijski izvještaji banaka čije dionice kotiraju na Zagrebačkoj burzi i koje svoje financijske izvještaje javno objavljuju na kvartalnoj osnovi, a to su: Hrvatska poštanska banka d.d., Karlovačka banka d.d., Privredna banka Zagreb d.d. i Zagrebačka banka d.d. Uvažavajući prethodno korišteni kriterij podjele banaka na „male“ i velike“, u odabranom uzorku nalazi se jedna „mala“ banka s 0,6 \% udjela u ukupnoj aktivi svih banaka i tri „velike“ banke s udjelom većim od $2 \%$ u ukupnoj aktivi svih banaka. Banke u uzorku obuhvaćaju $54 \%$ ukupne aktive svih banaka koje imaju sjedište u Republici Hrvatskoj. Analizirani su podaci objavljeni u financijskim izvještajima banaka za razdoblje od 1. 01. 2019. godine do 31. 12. 2019. godine budući da se u tom razdoblju provodilo istraživanje i sama implementacija MSFI-ja 16.

Za utvrđivanje utjecaja na financijske izvještaje, analizirani su bilanca i račun dobiti i gubitka pojedine banke za promatrano razdoblje. Pri analizi utjecaja primjene MSFI-ja 16 na financijske izvještaje banke naglasak je stavljen na pozicije na kojima se objavljuju podaci o operativnom najmu. U skladu s tim, u bilanci su analizirane pozicije „,materijalna imovina“ u aktivi i ,ostale financijske obveze“ kao dio financijskih obveza koje se mjere po amortiziranom trošku u pasivi. U računu dobiti i gubitka analizirane su pozicije „kamatni troškovi“ i ,troškovi amortizacije“. Utjecaj primjene MSFI-ja 16 na bilancu banke prikazan je u tablici 4., dok je utjecaj primjene MSFI-ja 16 na račun dobiti i gubitka banke prikazan u tablici 5.

Temeljem promjene na poziciji „materijalna imovina“ za 161.036.000 kuna (povećanje za 114,25 \%) u 2. kvartalu zaključuje se da je Hrvatska poštanska banka d.d. u tom razdoblju u svojoj bilanci inicijalno priznala ugovore o operativnom najmu. U istom razdoblju evidentirano je i značajno povećanje „ostalih financijskih obveza“ (za 85.425 .000 kuna odnosno za 955,32\%). Za očekivati je bilo da će doći do približno jednakih iznosa promjena na pozicijama „materijalna imovina“ $\mathrm{i}$, ostale financijske obveze“, međutim na temelju po- 
Tablica 4. Utjecaj primjene MSFI-ja 16 Najmovi na bilancu banke

\begin{tabular}{|c|c|c|c|c|c|}
\hline $\begin{array}{l}\text { Pozicija } \\
\text { (u tisućama kuna) }\end{array}$ & $\begin{array}{c}31.12 . \\
2018 .\end{array}$ & $\begin{array}{c}31.03 . \\
2019 .\end{array}$ & $\begin{array}{c}30.06 . \\
2019 .\end{array}$ & $\begin{array}{c}30.09 . \\
2019 .\end{array}$ & $\begin{array}{c}31.12 . \\
2019 .\end{array}$ \\
\hline \multicolumn{6}{|c|}{ Hrvatska poštanska banka d.d. } \\
\hline Materijalna imovina & 137.734 & 140.955 & 301.991 & 308.538 & 320.086 \\
\hline$\%$ promjene & & $2,34 \%$ & $114,25 \%$ & $2,17 \%$ & $3,74 \%$ \\
\hline $\begin{array}{l}\text { Ostale financijske } \\
\text { obveze }\end{array}$ & 7.390 & 8.942 & 94.367 & 93.863 & 112.476 \\
\hline$\%$ promjene & & $21,00 \%$ & $955,32 \%$ & $-0,54 \%$ & $19,83 \%$ \\
\hline \multicolumn{6}{|c|}{ Karlovačka banka d.d. } \\
\hline Materijalna imovina & 29.110 & 28.734 & 29.281 & 28.265 & 27.985 \\
\hline$\%$ promjene & & $-1,29 \%$ & $1,90 \%$ & $-3,47 \%$ & $-1,00 \%$ \\
\hline $\begin{array}{l}\text { Ostale financijske } \\
\text { obveze }\end{array}$ & 292 & 366 & 1.428 & 1.304 & 1.197 \\
\hline$\%$ promjene & & $25,34 \%$ & $290,16 \%$ & $-8,68 \%$ & $-8,21 \%$ \\
\hline \multicolumn{6}{|c|}{ Privredna banka Zagreb d.d. } \\
\hline Materijalna imovina & 636.495 & 950.381 & 952.203 & 954.758 & 977.523 \\
\hline$\%$ promjene & & $49,32 \%$ & $0,19 \%$ & $0,27 \%$ & $2,38 \%$ \\
\hline $\begin{array}{l}\text { Ostale financijske } \\
\text { obveze }\end{array}$ & 15.073 & 15.200 & 358.525 & 353.471 & 341.755 \\
\hline$\%$ promjene & & $0,84 \%$ & $2.358,72 \%$ & $-1,41 \%$ & $-3,31 \%$ \\
\hline \multicolumn{6}{|c|}{ Zagrebačka banka d.d. } \\
\hline Materijalna imovina & 1.146 .379 & 1.224 .696 & 1.217 .746 & 1.201 .004 & 1.016 .501 \\
\hline$\%$ promjene & & $6,83 \%$ & $-0,57 \%$ & $1,37 \%$ & $-15,36 \%$ \\
\hline $\begin{array}{l}\text { Ostale financijske } \\
\text { obveze }\end{array}$ & 373.776 & 331.553 & 539.194 & 512.708 & 438.988 \\
\hline$\%$ promjene & & $-11,30 \%$ & $62,63 \%$ & $-4,91 \%$ & $-14,38 \%$ \\
\hline
\end{tabular}

Izvor: obrada autora prema nerevidiranim kvartalnim financijskim izvještajima javno objavljenim na mrežnim stranicama Zagrebačke burze.

dataka iz bilance vidi se razlika u iznosu povećanja koju je teško objasniti bez detaljnijeg uvida u analitičke podatke. Na temelju podataka iz bilance Karlovačke banke d.d. može se zaključiti promatrajući zajedno efekte nastale na poziciji „,materijalna imovina“ i „ostale financijske obveze“ da su ugovori o operativnom najmu inicijalno priznati u 2 . kvartalu. Isto kao i kod Hrvatske poštanske banke d.d., i kod Karlovačke banke d.d. iznosi povećanja materijalne imovine i ostalih financijskih obveza nisu jednaki te bi za veću preciznost u tumačenju trebalo raspolagati dodatnim analitičkim podacima. Kod Privredne banke Zagreb d.d. vidi se značajno povećanje na poziciji ,materijalna imovina“ u 1. kvartalu, dok je povećanje na poziciji „ostale financijske obveze“ evidentirano u 2. kvartalu. Budući da su iznosi povećanja na ove dvije pozicije slični, zaključak je da su promjene na tim pozicijama odraz 
priznavanja ugovora o operativnom najmu. Međutim, postavlja se pitanje zašto se efekti priznavanja vide kroz dva razdoblja, a jedan od razloga može biti promjena metodologije prikaza stavki u bilanci (zbog zahtjeva regulatora - HNB, ECB, ali i zbog inicijative same banke). Posljedica promjene metodologije je gubitak konzistentnosti u usporedbi podataka tijekom određenog vremenskog razdoblja. Također i kod Zagrebačke banke d.d. povećanje na poziciji „materijalna imovina“ i na poziciji ,ostale financijske obveze“ nije evidentirano $\mathrm{u}$ istom razdoblju.

Tablica 5. Utjecaj primjene MSFI-ja 16 Najmovi na račun dobiti i gubitka banke

\begin{tabular}{|c|c|c|c|c|}
\hline $\begin{array}{l}\text { Pozicija } \\
\text { (u tisućama kuna) }\end{array}$ & 31. 03.2019. & 30. 06. 2019. & 30. 09. 2019. & 31. 12.2019. \\
\hline \multicolumn{5}{|c|}{ Hrvatska poštanska banka d.d. } \\
\hline Kamatni troškovi & 16.908 & 16.346 & 14.335 & 19.495 \\
\hline$\%$ promjene & & $-3,43 \%$ & $-12,30 \%$ & $36 \%$ \\
\hline Amortizacija & 12.157 & 12.566 & 12.592 & 38.564 \\
\hline$\%$ promjene & & $3,36 \%$ & $0,21 \%$ & $206,26 \%$ \\
\hline \multicolumn{5}{|c|}{ Karlovačka banka d.d. } \\
\hline Kamatni troškovi & 2.402 & 2.050 & 1.886 & 1.726 \\
\hline$\%$ promjene & & $-14,65 \%$ & $-8,00 \%$ & $-8,48 \%$ \\
\hline Amortizacija & 1.090 & 1.144 & 1.155 & 1.134 \\
\hline$\%$ promjene & & $4,95 \%$ & $0,96 \%$ & $-1,82 \%$ \\
\hline \multicolumn{5}{|c|}{ Privredna banka Zagreb d.d. } \\
\hline Kamatni troškovi & 55.713 & 47.612 & 43.320 & 42.425 \\
\hline$\%$ promjene & & $-14,54 \%$ & $-9,01 \%$ & $-2,07 \%$ \\
\hline Amortizacija & 43.088 & 41.783 & 43.574 & 45.331 \\
\hline$\%$ promjene & & $-3,03 \%$ & $4,27 \%$ & $4,03 \%$ \\
\hline \multicolumn{5}{|c|}{ Zagrebačka banka d.d. } \\
\hline Kamatni troškovi & 103.981 & 99.894 & 101.789 & 101.108 \\
\hline$\%$ promjene & & $-3,93 \%$ & $1,90 \%$ & $-0,67 \%$ \\
\hline Amortizacija & 51.560 & 54.320 & 52.118 & 51.607 \\
\hline$\%$ promjene & & $5,35 \%$ & $-4,05 \%$ & $-0,98 \%$ \\
\hline
\end{tabular}

Izvor: obrada autora prema nerevidiranim kvartalnim financijskim izvještajima javno objavljenim na mrežnim stranicama Zagrebačke burze.

Obzirom na povećanje iznosa materijalne imovine za $114,25 \%$ u 2. kvartalu u $\mathrm{Hr}$ vatskoj poštanskoj banci d.d., za očekivati je bilo da će u istom razdoblju značajno rasti i trošak amortizacije. U računu dobiti i gubitka takva se povezanost s bilancom ne može uočiti. Postoji mogućnost da banka nije evidentirala trošak amortizacije istovremeno kada je priznala imovinu s pravom uporabe $u$ aktivi bilance. Povezanost između priznavanja obveze 
Tablica 6. Utjecaj primjene MSFI-ja 16 Najmovi na financijske pokazatelje banke

\begin{tabular}{|c|c|c|c|c|c|c|c|c|c|c|c|c|}
\hline \multirow{2}{*}{$\begin{array}{l}\text { Banka } \\
\text { Pokazatelj }\end{array}$} & \multicolumn{3}{|c|}{$\begin{array}{c}\text { Zagrebačka } \\
\text { banka d.d. }\end{array}$} & \multicolumn{3}{|c|}{$\begin{array}{c}\text { Privredna banka } \\
\text { Zagreb d.d. }\end{array}$} & \multicolumn{3}{|c|}{$\begin{array}{c}\text { Hrvatska poštanska } \\
\text { banka d.d. }\end{array}$} & \multicolumn{3}{|c|}{$\begin{array}{c}\text { Karlovačka } \\
\text { banka d.d. }\end{array}$} \\
\hline & $\begin{array}{l}30.06 . \\
2018\end{array}$ & $\begin{array}{l}30.06 . \\
2019 .\end{array}$ & razlika & $\begin{array}{l}30.06 . \\
2018 .\end{array}$ & $\begin{array}{c}30.06 . \\
2019 .\end{array}$ & razlika & $\begin{array}{l}30.06 . \\
2018 .\end{array}$ & $\begin{array}{l}30.06 . \\
2019 .\end{array}$ & razlika & $\begin{array}{l}30.06 . \\
2018 .\end{array}$ & $\begin{array}{l}30.06 . \\
2019 .\end{array}$ & razlika \\
\hline Koeficijent vlastitog financiranja & 0,14 & 0,14 & $-0,01$ & 0,17 & 0,16 & $-0,01$ & 0,09 & 0,10 & 0,01 & 0,07 & 0,07 & 0,01 \\
\hline Koeficijent zaduženosti & 0,86 & 0,86 & 0,01 & 0,83 & 0,84 & 0,01 & 0,91 & 0,90 & $-0,01$ & 0,93 & 0,93 & $-0,01$ \\
\hline Koeficijent ulaganja u fiksnu imovinu & 0,09 & 0,09 & 0,00 & 0,06 & 0,08 & 0,03 & 0,13 & 0,18 & 0,06 & 0,21 & 0,17 & $-0,04$ \\
\hline Ekonomičnost ukupnog poslovanja & 1,72 & 1,78 & 0,06 & 1,63 & 1,70 & 0,07 & 1,25 & 1,35 & 0,09 & 1,14 & 1,38 & 0,24 \\
\hline Odnos kamatnih prihoda i rashoda & 7,06 & 7,98 & 0,92 & 8,32 & 11,39 & 3,07 & 5,48 & 8,67 & 3,19 & 4,77 & 7,18 & 2,41 \\
\hline Odnos prihoda i troškova & 3,20 & 3,26 & 0,07 & 2,89 & 3,12 & 0,24 & 2,79 & 3,53 & 0,74 & 2,35 & 2,41 & 0,05 \\
\hline ROE - rentabilnost kapitala & $5,65 \%$ & $7,03 \%$ & $1,38 \%$ & $4,52 \%$ & $5,39 \%$ & $0,87 \%$ & $4,85 \%$ & $5,37 \%$ & $0,53 \%$ & $2,58 \%$ & $8,56 \%$ & $5,97 \%$ \\
\hline ROA - rentabilnost imovine & $0,97 \%$ & $1,17 \%$ & $0,20 \%$ & $0,96 \%$ & $1,04 \%$ & $0,08 \%$ & $0,56 \%$ & $0,66 \%$ & $0,10 \%$ & $0,17 \%$ & $0,63 \%$ & $0,46 \%$ \\
\hline Marža kamata & $1,26 \%$ & $1,24 \%$ & $-0,02 \%$ & $1,40 \%$ & $1,31 \%$ & $-0,10 \%$ & $1,21 \%$ & $1,13 \%$ & $-0,08 \%$ & $1,27 \%$ & $1,19 \%$ & $-0,08 \%$ \\
\hline Zarada po dionici (EPS) & 2,72 & 3,50 & 0,78 & 31,78 & 38,22 & 6,44 & 46,61 & 60,99 & 14,38 & 0,22 & 0,83 & 0,62 \\
\hline
\end{tabular}

Izvor: obrada autora prema financijskim izvještajima objavljenim na internetskim stranicama Hrvatske narodne banke i Zagrebačke burze. 
po osnovi najmova i kamatnih troškova teško je identificirati, djelomično i zbog toga što pozicija „kamatni troškovi“ sadrži kamatne troškove koji nastaju temeljem različitih pasivnih poslova banke (primljeni krediti, depoziti i drugo). U razdoblju priznavanja efekata MSFI-ja 16 u bilanci Karlovačke banke d.d. primjetno je povećanje troškova amortizacije za 4,95 \%. Promjena iznosa troškova amortizacije je značajnija u odnosu na uobičajeno kretanje troškova amortizacije u toj banci te se može smatrati da je povećanje troškova amortizacije posljedica priznavanja ugovora o operativnom najmu u bilanci. Kod Privredne banke Zagreb d.d. povećanje troškova amortizacije evidentirano je u 3. kvartalu, što nije usklađeno s razdobljem inicijalnog priznavanja ugovora o operativnom najmu. U Zagrebačkoj banci d.d. značajnije povećanje troškova amortizacije zabilježeno je u 2 . kvartalu.

Nakon provedene analize utjecaja priznavanja ugovora o operativnom najmu u financijskim izvještajima banaka finalno se može zaključiti da je kod „velikih“ banaka puno teže prepoznati utjecaj MSFI-ja 16 na bilancu i račun dobiti i gubitka bez dodatnih analitičkih podataka. Kod Privredne banke Zagreb d.d. analizom je utvrđeno da je utjecaj MSFI-ja 16 na bilancu i račun dobiti i gubitka značajan, dok je kod Zagrebačke banke d.d. teško prepoznati utjecaj MSFI-ja 16 na bilancu i račun dobiti i gubitka. Kod „malih“ banaka utjecaj MSFI-ja 16 lako je prepoznat, no taj utjecaj nije značajan. Rezultati dobiveni analizom financijskih izvještaja vezano uz značajnost utjecaja MSFI-ja 16 na bilancu i račun dobiti i gubitka u skladu su s rezultatima prikupljenim putem anketnog upitnika.

S ciljem da se utvrdi utjecaj primjene MSFI-ja 16 na financijske pokazatelje, u tablici 6. dan je prikaz samo određenih financijskih pokazatelja i to onih koji u formuli za izračun uključuju one pozicije bilance i računa dobiti i gubitka na koje je evidencija ugovora o operativnom najmu sukladno MSFI-ju 16 imala utjecaj.

Banke koje su ispunile anketni upitnik smatraju da postoji utjecaj MSFI-ja 16 na bilancu i račun dobiti i gubitka, ali da taj utjecaj nije značajan. Na temelju izračuna odabranih financijskih pokazatelja može se zaključiti da su promjene vidljive na većini odabranih financijskih pokazatelja, ali da kod nijednog financijskog pokazatelja taj utjecaj nije značajan.

\section{ZAKLJUČAK}

Stupanjem na snagu MSFI-ja 16 došlo je do značajne promjene u računovodstvenoj evidenciji najmova kod najmoprimca. Primjenom MSFI-ja 16, najmoprimac je dužan u bilanci priznati imovinu s pravom uporabe za svaki najam i obvezu po osnovi najma. Posljedično, promjena modela računovodstva najmova uzrokovala je i određene promjene u financijskim izvještajima te je utjecala na financijske pokazatelje najmoprimca. Utjecaj MSFI-ja 16 na financijske izvještaje i financijske pokazatelje najmoprimca ovisi o značajnosti najma kao izvora financiranja pojedinog poslovnog subjekta, ukupnoj vrijednosti sklopljenih ugovora o operativnom najmu, iznosu aktive najmoprimca, udjelu vrijednosti ugovora o operativnom najmu u ukupnoj imovini najmoprimca, ali i o djelatnosti kojom se bavi odnosno sektoru kojem pripada. Banke imaju u najmu imovinu značajne vrijednosti (poslovne nekretnine, motorna vozila, bankomate, IT opremu i IT sustave i drugo), no pri analizi utjecaja primjene MSFI-ja 16 na banke treba uvažiti strukturu njihove bilance i iznos aktive. Rezultati istraživanja su pokazali da je utjecaj MSFI-ja 16 na bilancu veći kod banaka sa značajnom vrijednošću sklopljenih ugovora o operativnom najmu, dok utjecaj 
na račun dobiti i gubitka nije značajan ni kod najmoprimaca sa značajnom vrijednošću ugovora o operativnom najmu niti kod onih s malom vrijednošću ugovora o operativnom najmu. Rezultati empirijskog istraživanja pokazali su da se većina banaka slaže s inicijalnom tvrdnjom IASB-a da su financijski izvještaji najmoprimca transparentniji te da korisnici financijskih izvještaja imaju realniji uvid u financijski položaj i uspješnost poslovanja najmoprimca nakon primjene MSFI-ja 16. Prilikom implementacije MSFI-ja 16 banke su se susrele s nizom izazova, pri čemu je najveći izazov bila koordinacija aktivnosti između različitih odjela unutar banke, dok je najmanji izazov bio unos ugovora o operativnom najmu u sustav banke. MSFI 16 utjecao je i na financijske pokazatelje kod banaka na način da je došlo do porasta zaduženosti, smanjenja ekonomičnosti, smanjenja profitabilnosti imovine i kapitala, te pada marže kamata; dok jedino pokazatelj ulaganja u fiksnu imovinu raste i to zbog povećanja pozicije „,materijalna imovina“. Općenito se zaključuje da je utjecaj primjene MSFI-ja 16 veći što je vrijednost ugovora o operativnom najmu veća odnosno što je veći udio vrijednosti ugovora o operativnom najmu u ukupnoj imovini najmoprimca.

U praktičnom smislu, promjena modela računovodstva najmova može uzrokovati i određene promjene na leasing tržištu i to u dijelu koji se odnosi na pitanje o tome hoće li poslovni subjekti, uslijed kapitalizacije operativnih najmova, biti skloniji kupnji umjesto najmu imovine. Rezultati ovog istraživanja mogu biti korisni brojnim korisnicima financijskih izvještaja; investitorima pri donošenju odluka o investicijama, menadžerima pri donošenju odluka o kupnji ili najmu imovine, analitičarima pri procjeni rizika i ostalo.

U znanstvenom smislu doprinos ovog rada sadržan je, prije svega, u činjenici da je riječ o jednom od prvih istraživanja o stvarnim učincima MSFI-ja 16 na financijske izvještaje i financijske pokazatelje poslovnih subjekata nakon prve primjene standarda. Naime, prethodna istraživanja o problematici vezanoj uz kapitalizaciju ugovora o operativnom najmu temelje se na projekcijama i provedena su prije usvajanja finalne verzije MSFI-ja 16, ili projekcijama temeljenim na finalnoj verziji MSFI-ja 16 ali prije njegove primjene. Stoga, ovo istraživanje kao pionirsko istraživanje u ovome području može poslužiti kao temelj za buduća istraživanja vezanim uz područje primjene i učinaka primjene MSFI-ja 16.

Premda je ovo istraživanje generiralo nove spoznaje vezane uz stvarne učinke primjene MSFI-ja 16 na financijske izvještaje i financijske pokazatelje poslovnih subjekata koje mogu biti zanimljive širokom krugu korisnika, neophodno je ukazati i na ograničenja istraživanja. To su, prije svega, veličina uzorka te vremenski period obuhvaćen istraživanjem. Naime, uzorak istraživanja ograničen je na banke, dok ostale financijske institucije, poslovni subjekti iz nefinancijskog sektora te državne jedinice koji su značajni korisnici operativnog najma kao izvora financiranja nisu obuhvaćeni ovim istraživanjem. Stoga, rezultate dobivene ovim istraživanjem nije moguće generalizirati za cijelu populaciju odnosno za sve poslovne subjekte koji imaju sklopljene ugovore o operativnom najmu. U kontekstu vremenskog perioda koji je obuhvaćen ovim istraživanjem, važno je istaknuti da je on maksimalan u trenutku provedbe istraživanja budući da se radi o prvoj godini primjene standarda. Međutim, u budućim istraživanjima, poželjno je, pored proširivanja uzorka istraživanja na poslovne subjekte iz drugih sektora, proširiti i vremenski period koji će biti obuhvaćen istraživanjem. 


\section{LITERATURA}

1. Beattie, V., Edwards, K. \& Goodacre, A. (1998). The Impact of Constructive Operating Lease Capitalisation on Key Accounting Ratios. Accounting and Business Research, 28(4), 233-254.

2. Beattie, V., Goodacre, A. \& Thomson, S. J. (2006). International lease-accounting reform and economic consequences: The views of U.K. users and prepares. International Journal of Accounitng, 41(1), 75-103.

3. Bennett, B. K. \& Bradbury, M. E. (2003). Capitalizing Non-cancelable Operating Leases. Journal of International Financial Management and Accounting, 14(2), 101114.

4. Bohušová, H. (2015). Is Capitalization of Operating Lease Way to Increase of Comparability of Financial Statements Prepared in Accordance with IFRS and US GAAP?. Acta Universitatis Agriculturae et Silviculturae Mendelianae Brunesis, 63(2), 507514.

5. Deloitte (2016). IFRS 16 Leases: impact, challenges and solutions. Dostupno na: https://www2.deloitte.com/ce/en/pages/finevare/article/irrs-16-leases-impact-challenges-and-solutions.html

6. Deloitte (2019). IFRS 16: Leases and the Impact on Credit Institutions. Dostupno na: https://www2.deloitte.com/content/dam/Deloitte/cy/Documents/financial-services/ IFRS\%2016-\%20Leases\%20and\%20the\%20Impact\%20on\%20Credit\%20institutions.pdf

7. Duke, J. C., Hsieh, S. J. \& Su, Y. (2009). Operating and synthetic leases: Exploiting financial benefits in the post-Enron era. Advances in Accounting, 25(1), 28-39.

8. Dumičić, K., Bahovec, V., Čižmešija, M., Kurnoga Živadinović, N., Čeh Časni, A., Jakšić, S., Palić, I., Sorić, P., Žmuk, B. (2011). Poslovna Statistika. Zagreb: Element d.o.o.

9. Durocher, S. (2008). Canadian Evidence on the Constructive Capitalisation of Operating Leases. Accounting Perspectives, 7(3), 227-256.

10. ERA (2019). ERA Market Report 2019. Dostupno na: https://erarental.org/it/publications/era-rental-statistics/era-market-report-2019

11. Europska komisija, Službeni list Europske unije (2017). MSFI 16 Najmovi. Dostupno na: https://eur-lex.europa.eu/legal-content/HR/TXT/PDF/?uri=CELEX:32017 R1986\&from $=\mathrm{EN}$

12. Fitó, M. A., Moya, S. \& Orgaz, N. (2013). Considering the effects of operating lease capitalization on key financial ratios. Spanish Journal of Finance and Accounting, 42(159), 341-369.

13. Fülbier, U. R., Silva, J. L. \& Pferdehirt, H. M. (2008). Impact of lease capitalization on financial ratios of listed German companies. Schmalenbach Business Review, 60, 122-144.

14. Gulin, D., Vašiček, V., Dražić Lutilsky, I., Perčević, H., Hladika, M., Dragija Kostić, M. (2018). Računovodstvo II - evidentiranje poslovnih procesa. Zagreb: Hrvatska zajednica računovođa i financijskih djelatnika. 
15. HANFA (2020). Izvještaj o agregiranom financijskom položaju leasing društava. Dostupno na: https://www.hanfa.hr/publikacije/statistika/\#section5

16. Hassan, Y. (2018). IFRS 16: the challenge for banks. KPMG. Dostupno na: https:// assets.kpmg/content/dam/kpmg/ae/pdf/IFRS16.pdf

17. Hladika, M. (2018). Izazovi i promjene u računovodstvenom tretmanu najmova prema MSFI-ju 16 - Najmovi. Zbornik radova 21. međunarodnog simpozija BH MATRICA (str. 209-229). Sarajevo: FEB d.d.

18. Hladika, M. \& Valenta, I. (2018). Analysis of the effects of applying the new IFRS 16 Leases on the financial statements. U: Cingula, D. (ur.), Proceeding of the 36th International Scientific Conference on Economic and Social Development - „Building Resilient Society“, (str. 255-263). Varazdin Development and Entrepreneurship Agency, Varazdin, Croatia; University North, Koprivnica, Croatia; Faculty of Management University of Warsaw, Warsaw, Poland; Faculty of Law, Economics and Social Sciences Sale - Mohamed V University in Rabat, Morocco.

19. Hrvatska narodna banka, www.hnb.hr

20. IFRS Foundation (2016). Leases: A summary of IFRS 16 and its effects. Dostupno na: https://staff.ui.ac.id/martani/files/2017/07/ey-leases-a-summary-of-ifrs-16-andits-effects-may-2016.pdf

21. Leaseeurope (2019). Key Facts and Figures 2018. Dostupno na: https://www.leaseurope.org/_flysystem/s3?file=Statistics/LeaseuropeFF_18.pdf

22. Morales-Díaz, J. \& Zamora-Ramírez, C. (2018). The Impact of IFRS 16 on Key Financial Ratios: A New Methodological Approach. Accounting in Europe, 15(1), 105133.

23. Murphy, M. L. (2016). Bringing leases into view. Dostupno na: https://www.journalofaccountancy.com/issues/2016/apr/new-lease-accounting-standards.html

24. PWC (2016). IFRS 16: The Leases Standard is Changing - are you ready?. Dostupno na: https://www.pwc.com/gx/en/services/audit-assurance/assets/ifrs-16-new-leases. pdf

25. Reither, C. L. (1998). What are the best and the worst accounting standards?. Accounting Horizons, 12(3), 283-292.

26. Singh, A. (2012). Proposed Lease Accounting Changes: Implications for the Restaurant and Retail Industries. Journal of Hospitality \& Tourism Research, 36(3), 335365 .

27. Veverková, A. (2019). IFRS 16 and its impacts on aviation industry. Acta Universitatis Agriculturae et Silviculturae Mendelianae Brunensis, 67(5), 1369-1377.

28. Žager, K., Mamić Sačer, I., Sever Mališ, S., Ježovita, A., Žager, L. (2020) Analiza financijskih izvještaja: načela - postupci - slučajevi. 4. izdanje. Zagreb: Hrvatska zajednica računovođa i financijskih djelatnika.

29. Wong, K. \& Joshi, M. (2015). The Impact of Lease Capitalisation on Financial Statements and Key Ratios: Evidence from Australia. Australasian Accounting, Business and Finance Journal, 9(3), 27-44. 